\title{
Unconventional strategies for the Indian hotel industry during the slow down and its impact on value chain analysis.
}

\author{
Dr.Amarpreet Singh Ghura ${ }^{1}$, Jenny Mathew ${ }^{2}$ \\ 1,* Associate Professor, GuruNanak Institute of Management Studies, Mumbai And Student Of EPGDHRM At \\ Tata Institute Of Social Sciences. \\ ${ }^{2}$ Research Scholar At Tata Institute Of Social Sciences, Mumbai.
}

\begin{abstract}
Today India ranks the tenth-largest economy in the world by nominal GDP and the third-largest by purchasing power parity (PPP).The economy reported GDP growth around 4.7\% for the 2011-12 fiscal and $5.0 \%$ for the 2012-13 fiscal years. Indian rupee hit an all time low of 68.80 against the US dollar on 28 August 2013, which further impacted the growth of the Indian economy. Unavailability of land in the urban areas and the delay in securing government approvals stretched project outlays, undermining investor sentiment in the country. A prolonged global slowdown and a sharp deceleration in the Indian economy have been at the root of their misery over the last few years. High inflation, along with steady rise in food prices, rising interest rates and currency volatility has reduced margins of the companies and has impacted the profitability. Unfair, may be yes, but then that is the occupational hazard of any CEO in modern India. According to Moody's the Economic Growth Rate of India would be 5.5\% in 2014-15.But there has been hotels which has come up with optimization of existing resources to generate added revenues in times of slow down. The purpose of the paper is to present a short over view of the current Indian hotel industry and highlight the challenges facing the industry.Based on this perspective, the data is collected and after analyzing the data an attempt has been made to propose different unconventional strategies based on the minor operated departments of the hotels, which will be useful for the smooth functioning of the hotel industry, during the slowdown. The companies need to count every resource they own and align their every resource to be successful.
\end{abstract}

Keywords: Unconventional, Strategy, Slow down, Hospitality, Value chain.

\section{Introduction}

Decelerated Indian economy along with the slow down witnessed in the global economies has been the cause for the hard times in last one year for the tourism and hospitality industry in India. The other factors that has further intense the gravity of hard time is running inflation especially witnessed for the food and utility costs on one hand and the interest rates and currency volatility on the other, leading to compressed players margins and squeezed their profitability. Sheryl E Kimes (1989) in his paper has discussed revenue management and its possible implementation approaches and concerns to hotel managers by presenting necessary conditions for revenue management which are relatively fixed capacity, perishable inventory, reservation made in advance, appropriate cost structure, variable demand and segmentable markets. Unavailability of land, particularly in the metros, and the delay in securing government approvals stretched project outlays, undermining investor sentiment in the sector. The average hotel occupancy rate in India dropped to a low of 60.4 per cent in 2012-13, marginally higher than the 59.9 per cent occupancy of 2009-10. The average room rate also increased only marginally from Rs 4,487 in 2008-09 to Rs 4,507 in 2012-13, a Rs 20 increase over five years, according to Federation of Hotels \& Restaurant Associations of India. The net income for this period fell from 37.9 per cent to 30 per cent. In its September 2013 report, Indian Hotel Industry, ratings agency ICRA put out a negative outlook for the sector for 2013-14, stating, "With occupancy levels yet to firm up, we do not foresee adequate tractions in rates during the current fiscal."With such tough times the hoteliers have been forced to focus on their operating efficiently by focusing on their value chain. John Shank and V. Govindarajan (1993) describe the value chain in broader terms than does Porter. They state that "the value chain for any firm is the value-creating activities all the way from basic raw material sources from component suppliers through to the ultimate end-use product delivered into the final consumer's hands." This description views the firm as part of an overall chain of value-creating processes. A strategic tool to measure the importance of the customer's perceived value is value chain analysis. Michael Cusumano (2008)and others has concluded that Existing models of industry lifecycle evolution tend to focus on changes in the products and processes and largely overlook the dynamics of services, but increasingly, the revenues of many firms are becoming dominated by sales of services rather than products. While many hoteliers have reduced their staffing levels and are exploring other cost-cutting options, others are looking to cut idling costs and make every resource they own count. The technique of revenue management has potential application in many industries as long as customers view the resulting policies as being fair (Sheryl E Kimes 2003). This has some serious lessons for other industries. Competitive advantage for a company means 
not just matching or surpassing what competitors can do, but discovering what customers want and then profitably satisfying and even exceeding their expectations.

\section{Objective}

The objective of the paper is to present a short over view of the current Indian hotel industry and highlight the challenges facing the industry. Based on this perspective, the data is collected and after analyzing the data an attempt has been made to propose unconventional strategies and the alignment on the value chain, which will be useful for the smooth functioning of the hotel industry, during the slowdown.

\section{Methodology}

An Exploratory study was carried out in the current hotel industry in the city of Mumbai. The primary data is collected through personal interviews with over 100 managers in the hotels and experts who gave us the benefit of their extensive knowledge. A questionnaire was used for eliciting the manager's views in the Hotel industry. The questionnaire contained questions on influencing factor such as cost factors, occupancy rates, innovations and other related aspects such as use of technology. Also observations have been drawn through recent literature and studies on the changing elements that reinforce its impact on the performance and effectiveness of the hotel industry. In this paper on the basis of gathered information the new unconventional strategies has been proposed and future research has been recommended by the authors to examine any further gaps or inconsistence between the elements.

\section{Factors that increase complexity and influence the economic options available To Hotel operators include:}

- Globalization and market convergence - Due to the effects of liberalization, national markets are increasingly globalized which could be seen with the presence of Sheraton Group with its Four Ponits, Starwood, Inter Continental and Kempinski in India. This gives companies a chance to expand to new markets, but also increases the competition in traditional markets.

- Increasingly diversified consumer aggregate patterns of behavior - for instance the spending on the food and beverages (F\&B) has gained a place of importance, with the eating out culture seeing a steady uptick and hotels catering to walk-ins in equal numbers as hotel guests as consumers today want products and services that satisfy their individual requirements.

- Funding and Regulatory - India is considered to be an attractive market for both leisure and business travel, there are some inherent deficiencies due to which hospitality projects have hitherto taken long to come up including aspects like funding and regulatory issues.

- Taxation - The Indian hospitality sector had an added service tax imposed on all air-conditioned restaurants. Such taxation structures made Indian hospitality sector uncompetitive against its global peers, domestic firms face anywhere between $19-25 \%$ of overall taxes as against $8 \%$ on an average in international markets.

\section{Value Chain Analysis}

The idea of a value chain was first suggested by Michael Porter (1985) to depict how customer value accumulates along a chain of activities that lead to an end product or service. Porter describes the value chain as the internal processes or activities a company perform "to design, produce, market, deliver and support its product." Porter further states that "a firm's value chain and the way it performs individual activities are a reflection of its strategy, its approach to implementing its strategy and the underlying economics of the activities themselves.

Porter describes two major categories of business activities: primary activities and support activities. Primary activities are directly involved in transforming inputs into outputs and in delivery and after-sales support. These are generally also the line activities of the organization. They include:

Inbound logistics - material handling and warehousing.

Operations - transforming inputs into the final product.

Outbound logistics—order processing and distribution.

Marketing and sales - communication, pricing and channel management.

Service - installation, repair and parts.

Support activities are handled by the organization's staff functions and include:

Procurement — purchasing of raw materials, supplies and other consumable items as well as assets.

Technology development — know-how and technological inputs needed in every value chain activity. 
Human resource management-selection, promotion and placement; appraisal; rewards; management development; and labor/employee relations.

Firm infrastructure - general management, planning, finance, accounting, legal, government affairs and quality management.

\section{Paradigm Shift}

The reality is that industries never stand still, they continuously evolve, operations improve, markets expand and players come and go. History teaches us that we have hugely underestimated the capacity to re create existing industries Chain Kim \& Renee Mauborgne (1997). The hotel industry requires a shift of attention from supply to demand, from competing to value innovation, this is achieved via the concurrent chase of differentiation. The way how hotel industry has re created its sources of revenues in last one decade is very evident, for instance the revenue streams of a hotel were classified into five parts mainly: rooms, food and beverage, banquets and conferences, telephone and minor operated departments. The weightage of each of these revenue centers in last one decade has witnesses a shift. For example Telephone, has become redundant due to the advancements in telecommunication industry and has been replaced with the Wi-Fi. Similarly, F\&B has gained a place of importance, with the eating out culture seeing a steady uptick and hotels catering to walk-ins in equal numbers as hotel guests, leading to increase in the number of eating formats the hotels offer today. Further the paper focuses on converting the minor operated departments of hotels as a source of new revenue for the hotels.

\section{Proposed Strategy}

After collecting and analyzing the data and correlating the same with the existing practices within the hotel industry, the authors has made an attempt to propose unconventional strategy for the hotel industry i.e. looking at activating the ancillary departments of a hotel for extra revenues, which requires the hotels to align the value chain systems in order to be successful. Revenue management and its possible implementation approaches has concerns to hotel managers as there are necessary conditions for revenue management which are relatively fixed capacity, perishable inventory, reservation made in advance, appropriate cost structure, variable demand and segmentable markets (Sheryl E Kimes 1989). For instance every hotel has some minor operated departments which are termed as all the conceivable 'extras' that a hotel pools together in its customer service bid. Typically, it would include services such as laundry, gift shops, business centre, spa, gym, pool, news stand, parking, cabs etc. Now the strategy proposed talks about looking at activating the ancillary departments of a hotel for extra revenues, which requires hotels working out plans for its minor operating departments like laundry ,gym, pool, travel and spa to open up the services to the general public. The technique of revenue management has potential application in many industries as long as customers view the resulting policies as being fair (Sheryl E Kimes 2003). Till now the practice which the hotel players follow is not to allow the general public, who are not staying in the hotel, to use the services such as laundry, gym, spa, cabs etc, which turns the resources being underutilized due to the down turn in economy and leading to huge maintenance cost of such resources and leading a burden on the revenues of the hotel. Out of the 20 five star hotel analysed, non of them have allowed the general public to use the services of gym, laundary, spa, cabs etc. As per the decline in the occupancy rates the hotel cannot just not rely on hotel guests alone for using these departments optimally, opening up the services to the general public on annual membership basis, it will prove as a serious revenue generator. But the same will require a shift or aligning of the value chain because the fee charged would be prohibitive, ensuring that membership is regulated at the same time. For instance if the hotels will allow the general public to use the services like gym, spa, cabs etc, they will require some change in its value chain to make the operations successful and smooth, as rightly said that a shift in the corporate level strategy will have a reciprocate move in the business and the functional level strategy. Similarly, the hotel can tie up with partners for these departments, bringing in expertise and distancing it from non-core areas simultaneously. For example, the hotel which allows general public to use its gym can have a tie up or a strategic alliance with the established players in the gym industry, which has all the required expertise such as Mickey Mehta's Wellness Group for programmes at the hotel gym so that the brand value of the hotel doesn't get decline. Similarly if the hotel which is planning to allow general public to use its spa can have a tie up or a strategic alliance with the established players in the spa industry, which has all the required expertise such as Aristo, for its largely business traveler clientele, without having any damage to the existing brand value of the hotel and creating a value for the new set of customers. The other source of revenue-generation can be taking on outsourced laundry loads, as all 20 five star hotel which were surveyed had the requisite facility of in-house laundary, but all were operating on under utilization of the installed capacity. Penrose (1959) has argued that a firms resource can become unique and valuable overtime when they are interactively deployed through the processes and routines that the managers, operating as a team envision, implement and readjust. Managers play the leading role in choosing a firms path, the combination of resources it will deploy and nurture and the markets it will participate in (Castanias and 
Helfat 1991). Thus the proposed strategy talks about the hotels can start taking on outsourced laundry loads from smaller establishments in the near surrounding or from the budget hotel chain, which fails to have in-house laundry capabilities, as their focus being on cost leadership. The hotel taking on the job has dual advantage of earning extra revenue on one hand and using the installed the capacity optimally leading to benefits of economies of scale. One other benefit that the hotels have for taking an outsource laundry load is that the hotel can also take on a load from a regular guest on a chargeable basis, of course, even if they are not staying with them at that moment. For instance hotels do have several senior level corporate guests who stay with a particular hotel for lengthened time and even after they move out, though, they like to use the same hotel's laundry services. The hotels can extend them these services purely as a way of building and sustaining the relationships. But the proposed strategy foresees some changes to be made in the primary activities of Value chain analysis model of porter. For instance one of the challenge is of logistics i.e. one of the reasons why all hotels are not in a position to earn from the outsourced assignments. For any outsourced assignment, hotel needs to have a completely separate logistics mechanism which extends from right from the entrance to the in-and-out movement and storage of loads. Resources must also be deployed to sort out issues of mix ups, losses etc.

The other major area where in the hotels can look at activating the ancillary departments for extra revenues is the fleet of vehicles used for the guests. Now due to a drop in the occupancy rates hotels can outsource their fleet management to external partners who have car rentals as their core business i.e. a strategic alliance, with companies like Uber which is an American cab service-of sorts, which has launched its operations in India in September 2013 with Uber Black. Uber black is, a premier sedan-led, on-call cab service. Users can log on to the Uber app, check for the nearest available Uber cab and book a ride. The catch is that the cab pulling up at the consumer's doorstep is not owned by Uber. These are fleets attached to hotels or rental agencies that have signed on to take clients on behalf of Uber. They are not under any obligation to Uber and work in their free time and earn extra revenue for the hotels.

One of the findings in the research was that maximum hotels use the downtime to get the much needed chores done that may be an eyesore otherwise. For instance companies in the case of Club Mahindra which has different revenue model, where in the revenue comes from the annual maintenance fees. Since the company has more of the captive consumer base thus they do not face the pinch of falling occupancy. But since the company is in the same hotel industry getting away from the non-peak season is an inescapable reality. The rise of internet-based room reservation presents hoteliers with a strategic challenge of controlling their distribution, while also working with intermediaries that can help sell rooms (Bill Carroll \&Judy Siguaw 2003). So to get the extra revenues the company can focus on unconventional practice to put out select inventory with online travel agents like makemytrip.com, goibibio.com for non-members, this will have dual benefit of optimization of resources and revenue generation. At present the company uses the downtime to get the maintenance and cleanup programmes done and the staff uses its annual leave at this period, so that we are fully staffed during the peak season.

\section{Conclusion}

Today size of the organization is no longer a guarantee of success. With the dynamism in the Indian hotel industry, the success of the hotels depends on finding out new ways to create value if they are to prosper. Moreover their profitability will depends on exploiting value innovations, for which the hotels will have to constantly focus on the unconventional strategies and alignment of the value chain.

\section{Bibliography}

[1]. Bill Carroll \&Judy Siguaw (2003), "The evolution of electronic distribution: Effects on hotels and intermediaries, "Cornell Hotel and Restaurant Administration Quarterly, Vol. 44,Issue 4 (August 2003), pp 38-50.

[2]. Castanias \& Helfat (1991), Managerial resources and rents Management 17, pp 155-171.

[3]. Chan Kim \& Renee Mauborgne (1997), Value Innovations: The strategic logic of high growth, Harvard Business Review, January February Press, pp 103-112.

[4]. Chan Kim \& Renee Mauborgne (2005), Blue Ocean Strategy, How to create uncontested market space and make the competition irrelevant, Harvard Business School Press, pp 3-24.

[5]. Francina Orfila Sintes (2005), "Innovation activity in the hotel industry: Evidence from Balearic Islands, "Tourism Management, Vol. 26 Issue 6 (December 2005), pp 851-865.

[6]. Masoom Gupte (2014), Making downtime count, The Strategist, volume XVIII, no 231, pp1.

[7]. Michael Cusumano, Steve Kahl and Fernaando Suarez, (2006), MIT Sloan School of Management, USA, Paper no 228.Published on 7 June, 2006.

[8]. Penrose, E. T (1995), The Theory of the Growth of the Firm. $3^{\text {rd }}$ Ed, John Wiley and Sons, New York.

[9]. S.E.Kimes (1989), "The Basics of Yield Management, "Cornell Hotel and Restaurant Administration Quarterly, Vol. 30, No. 3 (June 1989), pp 14-19.

[10]. S.E.Kimes (2003), "Revenue Management: A retrospective, "Cornell Hotel and Restaurant Administration Quarterly, Vol. 44, No. 5-6 (October - December 2003), pp 131-138.

[11]. Yasemin Y. Kor (2003) "Experience-Based Top Management Team Competence and sustained growth, Informs, Vol. 14, No. 6 (November - December 2003), pp 707-719. 